\title{
Farmers' awareness and utilization of disaster management strategies and training needs for sustainable food security and livelihoods in Nigeria
}

\author{
N. T. Meludu \\ Department of Agricultural Extension and Rural Development, \\ University of Ibadan, Nigeria
}

\begin{abstract}
Disasters are extremely harmful to people and cause considerable loss to national economies. Food production in rural areas is especially vulnerable to disaster. Disaster management is therefore extremely important everywhere in the world, especially in developing countries. Agriculture concerns food production, and the consumption of food is a primary life prerequisite for all human beings wherever they are living on the globe. Agriculture is also one of the economic sectors that turns out to be the most affected by disasters. Integrating agriculture, livelihoods and environmental issues into disaster response efforts and risk reduction strategies is particularly important for poor communities, often resident on marginal lands, which are at greatest risk of natural disasters. That is the reason why this study is focused on the awareness and utilization of strategies for disaster management in agriculture. The result revealed that the higher percentage $(55 \%)$ of the respondents ranked flooding as the most severe risk, followed by erosion (20\%), pollution (10\%), and pest and disease outbreak (5\%) respectively. The majority of the respondents showed high training needs in the entire preventive and control methods of disaster risks. This corresponds with the respondents' lack of awareness of the disaster management strategies and the kind of risk these people face. This is an indication that the respondents have not received any training on disaster management and could be adopting poor strategies or no strategy at all. However, there is significant relationship between marital status $\left(\chi^{2}=5.134 ; \mathrm{p}=0.014\right)$ and level of education $\left(\left(\chi^{2}\right.\right.$ $=17.678 ; \mathrm{p}=0.001)$ and awareness. It was discovered that some of the farmers
\end{abstract}


lack the capability to effectively manage disaster, thereby losing their livelihoods. In making disaster risk reduction strategies more effective, a comprehensive approach to disaster management involves a number of actors and actions outside the expertise and realm of environmental organizations.

Keywords: livelihoods, environment, disaster, mortality, awareness, risk reduction, strategies, training, utilization, Nigeria.

\section{Introduction}

Globalization in the agricultural industry is increasingly competitive. In recent years, the world has witnessed a succession of disasters - floods, wildfires, storms, earthquakes, volcanic eruptions, and landslides. These claimed many thousands of lives, caused material losses in the billions of dollars, and inflicted a terrible toll on developing countries in particular, where disasters divert attention and resources from development needed desperately to escape poverty (UNDP [1]). It is a well-known fact that today's disasters are often generated by, or at least extended by, human activities (FAO [2]). At the most dramatic level, human activities are changing the natural balance of the planet and interfering with the atmosphere, oceans, polar ice caps, forest cover, and the pillars that make our world what it is (ISDA [3]). Population growth and associated pressures cause more people to live in flood plains or in areas prone to landslides. Inadequate land-use planning, poor environmental management and a lack of appropriate institutional and legislative arrangements increase the risk and multiply the effects of disasters. Living with risk is the order of the day, and there is the need to learn to reduce these risks through appropriate measures focused on planning, forecasting, and mitigation. There is the need to build a world of resilient people, communities, and nations. Gradually, environmental and development stakeholders are becoming more involved in the management of risk and vulnerability reduction due to their close interaction with natural resources management by creating awareness (Tigere Chagutah [4]).

The African Ministerial Statement to the World Summit on Sustainable Development states that the increased incidence of natural disasters in Africa poses a major obstacle to the African continent's efforts to achieve sustainable development, especially in view of the region's insufficient capacities to predict, monitor, handle, and mitigate natural disasters (South Africa [5], Marjanovic and Nimpuno [6]). Reducing the vulnerability of the African people to natural disasters and environmental risks is mentioned as a requirement to achieve the poverty reduction goals of the Millennium Declaration alongside other basic requirements, including economic growth, access to sources of energy, and basic health services. Nigeria has been experiencing quite a significant number of disastrous events of both natural and anthropogenic origin. Recent information on the hazard profile of the Nigeria and its vulnerability and capacity assessment shows that these disasters are related to drought, water and climate, fire disasters, locust invasion, environmental degradation, floods and epidemics. Disasters have caused great losses to lives and properties in Nigeria and have often pushed several people into poverty. The economic impact of disasters usually consists 
of direct damage e.g. infrastructure, crops, animals, housing, and indirect damage. The aftermath of these disasters is that it results to loss of revenues, unemployment and market destabilization. It is therefore increasingly becoming a major developmental issue of urgent concern for the government, development partners and local communities. Over the years, Nigerians have had to rely on share luck and providence to save them from disasters with little or no help coming from rescue agencies which lacks the capacity and wherewithal to intervene in such difficulty moments. Disasters derail socio-economic progress, and put millions of people into terrible poverty or make the poor even poorer. The need to systematically reduce the increased impact of disaster is steadily gaining recognition and commitment of government worldwide.

In 1990, Nigeria along with other member countries of the United Nations set up a National Committee for the International Decade for Natural Disaster Reduction (IDNDR). The Nigerian Inter-Ministerial body set up four subcommittees, with NERA retaining membership in each sub-committee, to address natural disasters reduction in Nigeria. A working group was also inaugurated with a representative from NERA to work out a situation report on Natural Disaster reduction for the country for the remaining years in the decade. This report was submitted in May 1994 and after this submission, the committee ceased to exist. This brought back the task of drawing up a National Agenda on the issue of disaster management in all its ramifications. This function of NERA with regards to Disaster Management was very limited because of the scope under which it operated. The National Emergency Management Agency (NEMA) was established via Act 12 as amended by Act 50 of 1999, to manage disasters in Nigeria. The establishment of NEMA, for more than ten years ago, ushers in a new dawn in disaster management from the hitherto narrow practice of relief distribution. Bracing up to the challenges of its given mandates, efforts were continuously made in putting together the necessary structures and sustained refocusing of programmes towards efficient and effective disaster management in the country. For the country to have an effective disaster management required "political and legal commitment, public understanding, scientific knowledge, careful development planning, responsible enforcement of policies and legislation, early warning systems and effective disaster preparedness and response mechanisms" (Audu-Bida [7]).

The authorities of the NEMA had rolled-out a three-year action plan since 2009 to train more than 154,800 volunteers on effective disaster response and control mechanisms. The focus at the flag-off a 3-day sensitization workshop on Disaster Risk Management for Public Officers in Kaduna that it planned to engage in the training and mobilization of 154,800 volunteers as part of Federal Government's new contingency plan to management disaster incident in the country. It was emphasized that about 200 volunteers would be drawn from each of the 774 local government areas of the country and would be adequately trained and equipped with all the techniques and skills to ensure prompt and effective response action during disaster. Disaster management requires not only emergency relief but political and legal commitment, public understanding, scientific knowledge, careful development planning, responsible enforcement of 
policies which should be responsive and proactive for the effective management of any emergency. While regretting the enormous loses that trail every disaster incident in the country in the past years. One major fall-out from the workshop is that while the number and gravity of disasters are on the increase locally and globally, the traditional strategies for disaster management through relief measures have become ineffective because they are largely reactive instead of being proactive in reducing the risk.

Disasters that were not properly managed have contributed significantly to loss of skilled personnel, diversion of scarce resources, and destruction of infrastructure, negative investment climate, political destabilization and loss of agricultural land. In the same vein, it was observed that the public, most especially the citizenry are not adequately informed and educated by the media and relevant information organs of government on potential areas of disasters, precautionary measures and expectations in case of disasters. While political and public attention has focused on the needs of urban areas, the state of preparedness among rural first-responder agencies has not been sufficiently addressed. Rural areas are home to nearly greater number of Nigerians and are the sites for food production security.

A substantial progress has not been made in incorporating disaster risk reduction (DRR) issues in educational system. Issues on hazards, vulnerability, DRR measures have not been placed in various text books from elementarysecondary to tertiary level of education. Different certificate courses, postgraduate diploma courses and Bachelor of Science are yet to be instituted. A regulatory and institutional framework for disaster management system is required to strengthen country's disaster management capacities. The challenges should be to have a paradigm shift from a reactive disaster response programme that is proactive to comprehensive risk reduction approaches, programme designing and implementation. Many public sectors officials posted for different disaster management agencies/responsibilities have experienced at some time in their careers the impact of flood they may not necessarily have the broader knowledge, skills set and experience required to enable them to drive strategic whole government risk reduction initiatives. In view of the longer term vision, it is important to strengthen the competency (knowledge, skills and attitude) of the people not only working in the national government system, but the common populace (example farmers) to be trained.

NEMA should be able to pre-empt devastating disasters in the country. In view of the fact that the media have active roles to play in creating public awareness on early warnings and proactive approach to curtail disaster, participants at the workshop were of the opinion that they should be involved in processes and programmes to achieve maximum results. Funding was seen as a major source of meeting target objectives and goals and as such, it was the general consensus that public awareness of disaster risk reduction should be adequately budgeted for by the government and donor agencies are made available for disaster management. 
NEMA caters for the special interest of the most vulnerable groups during disasters, a new unit has been created under the department to address the issues of women and children including those of the handicaps.

Hitherto, disaster management in country was mainly humanitarian relief supplies with huge funds expended annually on perennial emergencies. The paradigm shift in disaster risk management offers a good opportunity to build, develop and sustain policies pertaining to social development, equity, economic growth, environmental quality and sustainable land use. Experiences have revealed that in disaster management attention should be given to prevention and mitigation rather than to wait for the aftermath. NEMA has developed a special programme in this regard and with the cooperation of the stakeholders to embark on a series of training, sensitization and initiatives to promote the required consciousness on specific and general disasters. The programme emphasizes on the mainstreaming of disaster management into national development policies. But the question is, how is the rural populace, especially the farmers, to be educated on disasters and disaster management strategies so that they do not feel that whatever disaster that is affecting their area is not that the gods are angry with them? Despite Nigeria's being rich in agriculture resources, the agricultural sector has been growing at a very low rate. Less than 50 percent of the cultivable agricultural land is under cultivation. Even then, small holders and traditional farmers who use rudimentary production techniques with resultant low yields cultivate most of the lands. The small holder farmers are often constrained by many problems including those of poor access to modern inputs and credit, poor infrastructures, inadequate access to markets, land and environmental degradation, natural disasters, inadequate research and extension services. Three out four people in the developing countries live in rural areas and are highly dependent on agriculture for their food and livelihood. Disasters tend to have the most severe consequences on poor, vulnerable and agricultural-based population.

Therefore, the main objective of this study is to determine farmers' Awareness and Utilization of Disaster Management Strategies and Training Needs for Sustainable Food Security and Livelihoods in Nigeria. Poor farmers are neither aware of the tools and techniques for disaster management nor have the capacity to pay the premiums. More work needed before their large scale adoption in the developing countries like Nigeria. This is due to the fact that farmer maintain self-help groups to manage their own stocks of food, storage, seeds climate change and natural disasters.

\section{Methodology}

The case study area is Ogun state where there was a heavy flood in 2009 and even in 2010 that swept many homes and farm lands into water. Apart from Abeokuta, the capital, which is an important market centre-and a terminus of the roads and railways coming from Lagos and other parts of the country, there are also major towns and communities like Sagamu, Ijebu-Ode, IIaro and others that can serve as good markets for products of the mining industry in Ogun State. Ogun State is entirely in the tropics. Located in the Southwest Zone of Nigeria 
with a total land area of 16,409.26 square kilometres, it is bounded on the West by the Benin Republic, on the South by Lagos State and the Atlantic Ocean, on the East by Ondo State, and on the North by Oyo and Osun States. It is situated between Latitude $6.2^{\circ} \mathrm{N}$ and $7.8^{\circ} \mathrm{N}$ and Longitude $3.0 \mathrm{o} \mathrm{E}$ and $5.0^{\circ} \mathrm{E}$. The climate of Ogun State follows a tropical pattern with the raining season starting about March and ending in November, followed by dry season. The mean annual rainfall varies from $128 \mathrm{~cm}$ in the southern parts of the State to $105 \mathrm{~cm}$ in the northern areas. The average monthly temperature ranges from $23^{\circ} \mathrm{C}$ in July to $32^{\circ} \mathrm{C}$ in February. The northern part of the State is mainly of derived Savannah vegetation, while the Central part falls in the rain forest belt. The southern part of the State has mangrove swamp. The geographical landscape of the State comprises extensive fertile soil suitable for agriculture, and Savannah land in the north western part of the State, suitable for cattle rearing. There are also vast forest reserves, rivers, lagoons, rocks, mineral deposits and an oceanfront. Ogun State is blessed with many mineral deposits in commercial quantity. The list includes bitumen, kaolin, phosphate, bauxite, granite, limestone, crude oil and such others. The population of Ogun State during the 1991 Census was $2,333,726$. With its growth rate of 2.83 per cent per annum, the population estimate for 2003 was projected at 3,297,408 and 3,486,683 for 2005. The projections indicated that in 2003 , about $1,483,834$ of the population ( 45 per cent) would live in urban areas $1,813,574$ (55 per cent) in rural. Agriculture is the main occupation of the people, providing income and employment for a large percentage of the population. The State is blessed with a conducive climate that enhances cultivation of a variety of crops such as yam, cassava, maize, rice, plantain, beans, vegetables and citrus fruits such as orange, paw-paw, pineapple and so on. The main cash crops produced in the State are cocoa, cashew, kola nut, oil palm and palm kernels, rubber and coffee.

\subsection{Sampling technique and sample selection}

The population for this study involved all the farmers in the study area. Out of the twenty four local government areas in Ogun state, two (Ifo and Ogun waterside) LGAs were purposively chosen for the study because of the series incidents of floods and other disasters in the area which have affected agricultural production in the area. Fifty farm head of farm households were randomly selected for the study in each LGA, making a total of 100 respondents. Structural questionnaire with open ended questions was used to collect data from the respondents.

\subsection{Data analysis}

Data collected were subjected to both descriptive and inferential statistical analysis, such as frequency, percentage, and Chi-square. 


\section{Result and discussion}

This section starts by presenting results on frequency and percentage on personal characteristics of the respondents.

Table 1: Distribution of the personal characteristics of the respondents $(\mathrm{n}=$ 100).

\begin{tabular}{|l|r|r|}
\hline Personal Characteristics & Frequency & Percentage \\
\hline Age & & \\
$20-29$ & 5 & 5.0 \\
$30-39$ & 15 & 15.0 \\
$40-49$ & 20 & 20.0 \\
$50-59$ & 36 & 36.0 \\
$60+$ & 24 & 24.0 \\
\hline Sex & & \\
Male & 55 & 55.0 \\
Female & 45 & 45.0 \\
\hline Marital status & & \\
Single & 5 & 5.0 \\
Married & 95 & 95.0 \\
\hline Educational Attainment & & \\
Non-formal education & 31 & 31.0 \\
Adult literacy & 8 & 8.0 \\
Primary school education & 14 & 14.0 \\
Secondary education & 20 & 20.0 \\
Tertiary education & 27 & 27.0 \\
\hline
\end{tabular}

Table 1 reveals that majority of the respondents (36\%) are between the age range of 50-59 years old. Also substantial percentages of the respondents (24 and 20\%) are between the ages of 60 and above and 40-49 years old respectively. Age is an important personal characteristic to determine how active the respondents are. Unfortunately, majority of the respondents are very old. This will affect them in actively participating in disaster risk management and may find it difficult to escape. Majority of the respondents (55\%) are male while high percentage $(45 \%)$ is female. This shows that more males are involved in agriculture in this area. This is also an added advantage because women are more vulnerable in disaster risks.

A high proportion of the respondents $(95 \%)$ are married while very few $(5 \%)$ are single. Married people are more respected in the study area and they are also more responsible and serious in their job. Education is very important in all human activities and will enable the respondents to acquire more training for sustainability of life. Table 4 shows that high proportion $(31 \%)$ of the respondents had non-formal education, that is why few $(8 \%)$ of the respondents have participated in adult literacy to help them cope in life. Majority (61\%) had primary, secondary and tertiary education. This shows that rural people are becoming more educated in recent time than before. 
Table 2: Distribution on sources of information by the respondents $(\mathrm{n}=$ 100).

\begin{tabular}{|l|c|c|}
\hline Source of Information & Frequency & Percentage \\
\hline Newspaper & 5 & 5.0 \\
\hline Radio & 15 & 15.0 \\
\hline Television & 5 & 5.0 \\
\hline Friends/relations & 15 & 15.0 \\
\hline Local leaders & 25 & 25.0 \\
\hline Extension agent & 5 & 5.0 \\
\hline Local means of passing information (i.e. town crier) & 25 & 25.0 \\
\hline NEMA official & 5 & 5.0 \\
\hline
\end{tabular}

Table 3: $\quad$ Types of environmental risks in order of severity $(n=100)$.

\begin{tabular}{|l|l|l|}
\hline Type of environmental problem & $\begin{array}{l}\text { Rank in severity of the } \\
\text { problem (Frequency) }\end{array}$ & Percentage \\
\hline Flooding & 55 & 55.0 \\
\hline Erosion & 20 & 20.0 \\
\hline Pollution & 10 & 10.0 \\
\hline Pest infestation & 5 & 5.0 \\
\hline Disease out break & 5 & 5.0 \\
\hline Drought & 3 & 3.0 \\
\hline Fire & 2 & 2.0 \\
\hline
\end{tabular}

Table 4: $\quad$ Level of awareness of disaster risk factors.

\begin{tabular}{|l|l|l|l|l|}
\hline $\begin{array}{l}\text { Awareness of } \\
\text { environmental } \\
\text { risks factors }\end{array}$ & $\begin{array}{l}\text { Low awareness } \\
\text { (Frequency) }\end{array}$ & Percentage & $\begin{array}{l}\text { High } \\
\text { awareness } \\
\text { (Frequency) }\end{array}$ & Percentage \\
\hline Flooding & 75 & 75.0 & 25 & 25.0 \\
\hline Erosion & 65 & 65.0 & 45 & 45.0 \\
\hline Pollution & 80 & 80.0 & 20 & 20.0 \\
\hline Pest infestation & 55 & 55.0 & 45 & 45.0 \\
\hline Disease out break & 85 & 85.0 & 15 & 15.0 \\
\hline Drought & 78 & 78.0 & 22 & 22.0 \\
\hline Fire & 50 & 50.0 & 50 & 50.0 \\
\hline
\end{tabular}

Table 2 reveals that majority (25\%) of the respondents receives information about disaster and disaster management from the local leaders and local means of passing information respectively. Fifteen percent of the respondents receive information from the radio. A high percentage, $(15 \%)$ receive information from friends and relations. While very few $(5 \%)$ of the respondents receive information from the newspaper and television respectively. The problem of epileptic power supply may not enable the respondents to utilize television. 
Table 5: Distribution of the respondents on training needs $(\mathrm{n}=100)$.

\begin{tabular}{|c|c|c|}
\hline Level of need & & \\
\hline \multicolumn{3}{|c|}{ Radio weather reading } \\
\hline & Frequency & percentage \\
\hline High need & 93 & 93.0 \\
\hline Low need & 17 & 17.0 \\
\hline \multicolumn{3}{|c|}{ Training on flood prevent/control } \\
\hline High need & 88 & 88.0 \\
\hline Low need & 12 & 12.0 \\
\hline \multicolumn{3}{|c|}{ Erosion prevention/control } \\
\hline High need & 78 & 78.0 \\
\hline Low need & 22 & 22.0 \\
\hline \multicolumn{3}{|c|}{ Mobilize communities to take disaster preparedness } \\
\hline High need & 87 & 87.0 \\
\hline Low need & 13 & 13.0 \\
\hline \multicolumn{3}{|c|}{$\begin{array}{l}\text { Revival of indigenous food storage and prevention } \\
\text { techniques and planting of trees }\end{array}$} \\
\hline High need & 56 & 56.0 \\
\hline Low need & 44 & 44.0 \\
\hline \multicolumn{3}{|c|}{ Improved farming techniques } \\
\hline High need & 78 & 78.0 \\
\hline Low need & 22 & 22.0 \\
\hline \multicolumn{3}{|c|}{ Transferring the risk (Insurance) } \\
\hline High need & 90 & 90.0 \\
\hline Low need & 10 & 10.0 \\
\hline \multicolumn{3}{|c|}{ Water resources management } \\
\hline High need & 86 & 86.0 \\
\hline Low need & 14 & 14.0 \\
\hline \multicolumn{3}{|c|}{ Proper land use management } \\
\hline High need & 67 & 67.0 \\
\hline Low need & 33 & 13.0 \\
\hline \multicolumn{3}{|c|}{ Biodiversity conservation } \\
\hline High need & 56 & 56.0 \\
\hline Low need & 44 & 44.0 \\
\hline \multicolumn{3}{|c|}{ Pollution prevention and control } \\
\hline High need & 66 & 66.0 \\
\hline Low need & 34 & 34.0 \\
\hline \multicolumn{3}{|c|}{ Pests prevention/control } \\
\hline High need & 70 & 70.0 \\
\hline Low need & 30 & 30.0 \\
\hline \multicolumn{3}{|c|}{ Disease prevention/control/immunization } \\
\hline High need & 91 & 91.0 \\
\hline Low need & 9 & 9.0 \\
\hline \multicolumn{3}{|c|}{ Fire prevention/control } \\
\hline High need & 67 & 67.0 \\
\hline Low need & 33 & 33.0 \\
\hline
\end{tabular}


Table 6: Distribution of the constraints faced the respondents $(n=100)$.

\begin{tabular}{|l|l|l|}
\hline & Frequency & Percentage \\
\hline Inadequate capital to cope with risk & 68 & 68.0 \\
\hline Flood & 97 & 97.0 \\
\hline Erosion & 78 & 78.0 \\
\hline Pollution & 68 & 68.0 \\
\hline Inaccessibility of good water & 75 & 75.0 \\
\hline Diseases & 68 & 68.0 \\
\hline Pest & 45 & 45.0 \\
\hline High mortality & 50 & 50.0 \\
\hline Lack of credit facility & 82 & 82.0 \\
\hline Poor weather condition & 79 & 79.0 \\
\hline Lack of labour & 56 & 56.0 \\
\hline
\end{tabular}

However, the can easily use battery to power their radios in order to receive information. Agricultural extension (5\%) and NEMA (5\%) who are actually responsible to the farmers and disaster information are not always available. Table 3 revealed that higher percentage (55\%) of the respondents ranked flooding as the most severe risk, followed by erosion $(20 \%)$, pollution $(10 \%)$, and Pest and disease outbreak (5\%) respectively.

Awareness generation is very important to determine whether the respondents are aware of the risk factors associated with natural disaster. This is because of the fact that the rural people have different believes when such risks occur. Some time they think that it is caused by witches and wizards and or a kind of bad omen. More than half of the disasters in the country are man-made arising from deliberate intent, error or negligence. Disasters of man-made origin can be minimized by arousing the consciousness of the people through awareness generation.

The Agency utilizes awareness generation against disasters as the cornerstone in building a culture of sustainable resilience to disasters. Table 4 shows that majority of the respondents have low awareness on the risk factors of disasters.

The importance of this type of training is with respect to the effectiveness of disaster response. Table 3.5 indicated that majority of the respondents showed high training needs in the entire preventive and control methods. This corresponds with the respondents' lack of awareness of the disaster management strategies and the kind of risk these people face. This is an indication that the respondents have not received any training on disaster management and could be adopting poor or no strategy.

Table 6 reveals that the major constraints faced by the respondents include inadequate capital to cope with risk (68\%), flood (97\%), erosion (78\%), pollution $(68 \%)$, inaccessibility of good water $(75 \%)$, diseases $(68 \%)$, pest $(45 \%)$, high mortality $(50 \%)$, lack of credit facility $(82 \%)$, poor weather condition (79\%) and lack of labour $(56 \%)$. All these problems need to be addressed for sustainability of agricultural production, food security and livelihoods. 
Table 7: Chi-square statistics on the relationship between personal characteristic of the respondents and awareness of disaster management strategies.

\begin{tabular}{|l|l|l|l|l|}
\hline Variables & $\chi^{2}$ & df & P-value & Decision \\
\hline Sex & 0.143 & 1 & 0.612 & Not Significant \\
\hline Marital status & 5.134 & 1 & 0.014 & Significant \\
\hline Level of education & 17.678 & 5 & 0.001 & Significant \\
\hline
\end{tabular}

Table 7 shows that there is no significant relationship between sex and awareness to disaster management strategies at $(\mathrm{p}>0.05)$. This means that whether you are a male or female does not guarantee access to information on disaster management strategy. However, there is significant relationship between marital status $\left(\chi^{2}=5.134 ; \mathrm{p}=0.014\right)$ and level of education $\left(\left(\chi^{2}=17.678 ; \mathrm{p}=\right.\right.$ $0.001)$, which means that marital status has influence on awareness to disaster management strategies.

Table 8 revealed no significant relationship between the awareness of all the respondents and selected training needs at $\mathrm{p}>0.05$. This was shown in the previous result on low awareness and high need for training by the respondents. It also means that whether the respondents are aware or not does not influence the desire for training.

Table 8: Chi-square statistics on the relationship between the respondents' awareness and selected training needs.

\begin{tabular}{|l|l|l|l|l|}
\hline Variables & $\chi^{2}$ & df & $\begin{array}{l}\text { P- } \\
\text { value }\end{array}$ & Decision \\
\hline Radio weather reading & 2.552 & 1 & 0.281 & $\begin{array}{l}\text { Not } \\
\text { significant }\end{array}$ \\
\hline Training on flood prevent/control & 1.006 & 1 & 0.901 & $\begin{array}{l}\text { Not } \\
\text { significant }\end{array}$ \\
\hline Erosion prevention/control & 0.115 & 1 & 0.725 & $\begin{array}{l}\text { Not } \\
\text { significant }\end{array}$ \\
\hline $\begin{array}{l}\text { Mobilize communities to take disaster } \\
\text { preparedness }\end{array}$ & 1.565 & 1 & 0.212 & $\begin{array}{l}\text { Not } \\
\text { significant }\end{array}$ \\
\hline Transferring the risk (Insurance) & 0.119 & 1 & 0.650 & $\begin{array}{l}\text { Not } \\
\text { significant }\end{array}$ \\
\hline Proper land use management & 0.123 & 1 & 734 & $\begin{array}{l}\text { Not } \\
\text { significant }\end{array}$ \\
\hline Pollution prevention and control & 1.087 & 1 & 0.186 & $\begin{array}{l}\text { Not } \\
\text { significant }\end{array}$ \\
\hline Disease prevention/control/immunization & 0.288 & 1 & 0.687 & $\begin{array}{l}\text { Not } \\
\text { significant }\end{array}$ \\
\hline
\end{tabular}




\section{Conclusion}

Farmers are well aware of disaster risks but highly not aware of disaster management strategies in the study area. They face lots of challenges in risk reduction in the promotion of health, immunization, advocacy; mitigation in information, education, communication, insurance advocacy; preparedness in situation analysis, hazard mapping, contingency planning, early warning, education; during disaster management in drug distribution, personnel deployment and counselling. This is why they have high desire for training for all disaster risks in the area. It is more valuable to build more effective strategies for adapting to disaster risks better training will lead to efficient reduction and mitigation of disaster risks for sustainable food security and livelihoods.

\section{Recommendations}

Reduction and mitigation of disaster requires multi-disciplinary research and multi-institutional, participatory effort involving scientific, development and user communities. The guiding principles for disaster risk reduction strategies in Nigeria should be initiated and implemented, especially in the areas of poverty reduction, disaster prevention, capacity building of communities, partnership with the other tiers of government, education to increase public awareness and establishment of information networks. The enabling legislation for disaster risk management in Nigeria, such as the NEMA establishment Act should be amended to strengthen coordination of disaster management in order to be more efficient and effective. The new engagement in disaster management presupposes that states and local government councils across the country should take more proactive stance in the whole effort. Support to National Curriculum and Text Book Board (NCTB), public and private universities, and research institutes to strengthen the capacities to incorporate risk reduction issues in existing courses, degree programme and to introduce new courses and carry out research initiatives. Support to public and private training institutes and academics to strengthen the capacities to incorporate risk reduction in existing training programmes, courses. The following risk management strategies in agriculture could involve:

1. Avoiding the dangers,

2. Preventing/reducing the frequency of impacts,

3. Controlling/reducing the consequences (coping and adaptation measures),

4. Transferring the risk (e.g. insurance),

5. Responding appropriately to incidents/accidents (e.g. disaster management),

6. Recovering or rehabilitating as soon as possible (e.g. media response). 


\section{References}

[1] UNDP Multi-Sectoral Disaster Management And Emergency Response Strategy For SADC page 10-50. 2001

[2] FAO. Disaster Management in Food and Agriculture. 2008, 2010. http://documents.wfp.org/stellent/groups/public/documents/communications /wfp201794.pdf accessed 2010

[3] ISDR (International Strategy for Disaster Reduction) "Disaster Reduction and Sustainable Development." ISDR Background document for the World Summit on Sustainable Development (WSSD) N5. 2002.

[4] Tigere C. Towards improved public awareness for climate related disaster risk reduction in South Africa: A Participatory Development Communication perspective JÀMBÁ: Journal of Disaster Risk Studies, Vol. 2, No.2, November 2009 117-121. 2009

[5] South Africa. National Disaster Management Centre Inaugural Annual Report 2006/2007. Department of Provincial and Local Government. Pretoria: Government Printer. 2007

[6] Prvoslav Marjanovic and Krisno Nimpuno Living with Risk: Toward Effective Disaster Management Training. In Africa Disaster in Building Safer Cities: The Future of Disaster Risk Edited by Alcira Kreimer, Margaret Arnold and Anne Carlin. Risk Management Series. The World Bank Disaster Management Facility, Washington, D.C. pp. 197-209. 2003

[7] Audu-Bida, Nigeria: Disaster management, what can NEMA offer? Jan 2, 2009. 